\title{
Realising M-Payments: Modelling Consumers' Willingness to M-Pay Using Smart Phones
}

\author{
Aidan Duane \\ The School of Business, Department of Accounting and Economics, Waterford Institute \\ of Technology, Waterford City, Ireland \\ The School of Business, Department of Accounting and Economics, Waterford Institute \\ of Technology (WIT), Office No. D29, Cork Road Campus, Waterford City, County \\ Waterford, Ireland. \\ E-mail: $\underline{\text { aduane@wit.ie }}$
}

\section{Philip O'Reilly}

Department of Accounting, Finance and Information Systems, University College Cork, Cork, Ireland

Department of Accounting, Finance and Information Systems, University College Cork, 3.87, O’Rahilly Building, College Road, Cork, Ireland

E-mail: philip.oreilly@ucc.ie

\section{Pavel Andreev}

Telfer School of Management, University of Ottawa, Ottawa, Canada

Telfer School of Management, University of Ottawa, 55 Laurier Ave. East, Desmarais Building, Ottawa, ON, K1N 6N5, Canada

E-mail: andreev@telfer.uottawa.ca 


\title{
Realising M-Payments: Modelling Consumers' Willingness to M-Pay Using Smart Phones
}

\begin{abstract}
It is predicted that significant and ongoing investment in M-Commerce platforms and application development by commercial entities, will fundamentally change consumers' shopping and web browsing behaviours. However, the evolving behaviour of Smart Phone users is somewhat tempered by concerns over MPayments. If Smart Phones are to reach their full M-Commerce potential, the ability of consumers to transact and pay for products/services through these devices in an easy, safe, and reliable manner, must be addressed. In response, this paper contributes a theoretical model, and empirically tests the model to explore Irish consumers' perceptions of using Smart Phones to make M-Payments for products/services. The findings present conclusive evidence that trust is the most powerful factor influencing consumers' willingness to use Smart Phones to make M-Payments. While perceived usefulness and perceived ease of use influence the payment decision, their impact is much lower. Mobile self-efficacy and personal innovativeness have almost no direct impact. The paper concludes that irrespective of individuals' high levels of personal innovativeness, or mobile selfefficacy, and irrespective of whether Smart Mobile Media Services are perceived as useful and easy to use, consumers will not make M-Payments, until they are convinced that Smart Phone M-Payment systems are safe and reliable.
\end{abstract}

Keywords: Smart Phones, User Behaviour, M-Payments, Trust, PLS.

\section{Introduction}

The notion that Smart Phones could become valuable and critical business tools for the delivery of M-Commerce products and services, has long been touted by academics, professionals, and the media (Varshney and Vetter 2002; Bauer et al. 2005; Leppäniemi and Karjaluoto 2005; Gao and Küpper 2006; Hsu and Kulviwat 2006). Smart Phones enable the delivery of a wide range of transactional M-Commerce products and services, including highly individualised and location-based Smart Mobile Media Services (SMMS) (O’Reilly and Duane 2010). Smart Mobile Media Services (SMMS): 
“...provide mobile network subscribers with permission and subscription-based, dynamically profiled, location, context and task specific, mobile Internet applications, content, products, services and transactions for Smart Phones".

(O’Reilly and Duane 2010, p.197)

In particular, location-based SMMS have resulted in substantial changes to consumers' interactions with retailers via the mobile web, especially when coupled with mobile couponing (Jayasingh and Eze 2009; Goldman 2010). Thus, SMMS are integral to the M-Commerce value chain proposition. Numerous industry experts predict that the range and extent of SMMS available through Smart Phones and other Smart Mobile Media Devices (SMMD), will increase significantly over the coming years, as increasing numbers of commercial entities invest in M-Commerce platforms and applications, to satisfy growing consumer demands for fully fledged multichannel retailing (Skeldon 2011). Significant investment has taken place in recent times on MCommerce platforms and application development by major global organisations such as, KFC (Higgs 2008), Starbucks (Xu et al. 2010), Microsoft, McDonalds, Coca-Cola, and P\&G (Wei et al. 2010). Indeed it is significant that WorldNet TPS predicts that MCommerce will achieve in the next three to four years, what E-Commerce has achieved in the last 15 years (Enterprise Ireland 2011).

When considering the future of M-Commerce and realisation of the potential of Smart Phones, the establishment of standardised, interconnected and widely-accepted mobile payment (M-Payment) procedures is crucial (Zhong 2009). It is predicted that M-Payments, using mobile devices for digital and physical goods, could exceed $\$ 630$ billion in 2014 alone (Juniper Research 2010). According to Egger (2001), trust in any payment system is influenced by anonymity, security, reliability, the amount of control that users have, and the reputation of the entity that introduces the system. One must also recognise that the "M-Payments Process" requires specialised M-Payment 
hardware and software, a vendor accepting the M-Payment, an M-Payment processing service, legislation and consumer rights governing the M-Payment process, and an independent consumer rights advocate regulating the process (Ondrus et al. 2009; Ondrus and Lyytinen 2011). This multi-dimensionality of trust in M-Payments is reflected in the definition of M-Payments adopted for this study. The authors adopt the definition provided by Dinez et al. (2011) who define M-Payments as:

"payments made or enabled through digital mobility technologies, via handheld devices, with or without the use of mobile telecommunications networks. These payments are digital financial transactions, although not necessarily linked to financial institutions or banks" (p.5).

In some countries including Japan, Singapore, and Korea, M-Payment services have become established and widely used (Schaettgen and Taga 2010). However, in a global context, and particularly in Europe, M-Payments are still in their infancy. In fact, Schierz et al. (2010) report that less than $1 \%$ of mobile phone users have made an MPayment. Interestingly, several researchers (Barutcu 2008; Matthews et al. 2009; Xu et al. 2010; Andreev et al. 2011; Rao 2011) reveal that while consumers have positive attitudes towards mobile advertising, mobile coupons, mobile social media, and mobile media, they do not possess positive attitudes towards mobile shopping, and in particular making M-Payments using Smart Phones. And herein lies the problem; although growth forecasts for M-Payment services have been very positive, the reality on the ground is quite different (Schierz et al. 2010). These studies indicate that while consumers are willing to use Smart Phones to engage in M-Commerce transactional tasks, they are reluctant to make an M-Payment. This is very significant, as the realisation of the enormous commercial potential of Smart Phones for M-Commerce is entirely contingent on consumers' willingness to make an M-Payment using Smart Phones, and as such complete the M-Commerce transactional loop. Thus, the primary question 
emerging from the extant literature is - what factors influence consumers' willingness to use a Smart Phone to make M-Payments?

\subsection{Review of the Literature: State of the Art}

Few comprehensive attempts have been made already by researchers to answer this question with extant studies focusing on the broader field of M-Commerce. Kim and Zhang (2009) suggest that although there can be numerous factors influencing people's adoption of Smart Phone services, such factors are under-investigated in the extant literature. While some M-Commerce based adoption studies have been conducted, they have been primarily focused on mobile marketing/advertising and mobile banking adoption. Bauer et al. (2005) reveal the importance of personal innovativeness in the adoption of mobile marketing. Similarly, Gupta et al. (2011) note that personal innovativeness has a positive impact on willingness to use mobile location-based services (LBS). Lee et al. (2011) suggest that mobile self-efficacy (MSE) influences consumers' adoption of mobile advertising. Chen et al. (2011) tested TAM in a study on Smart Phone acceptance, and reports that MSE also plays a positive role on perceived ease of use.

A number of researchers (Siau et al. 2004; Xu and Gutierrez 2006; Mallat 2007) suggest that trust positively influences consumers' decisions to engage in M-Commerce transactional tasks. Lin and Wang (2006) reveal that trust also has a positive impact on consumer loyalty and satisfaction towards M-Commerce. Chung and Kwon (2009) and Lie et al. (2010) suggest that consumers' perceptions of competence, integrity, and ethical commitment in mobile banking and M-Commerce were also important trust factors influencing adoption decisions. Previously, trust has been identified as a significant determinant in influencing consumers' E-Commerce transactions in several studies (e.g. Jarvenpaa et al. 2000; Gefen et al. 2003; Verhagen et al. 2006; Chen and 
Barnes 2007). Some E-Commerce studies reveal that trust factors such as perceived security control, perceived privacy control (Cheung and Lee 2003; Roca et al. 2008), perceived integrity, and perceived competence (Cheung and Lee 2003) greatly influence a consumers trust in online vendors, and thus their adoption decisions. Governance and independent regulation of the online E-Commerce environment are also trust factors that influence adoption according to Cheung and Lee (2003).

Viehland and Yoong Leong (2010) and Dahlberg et al. (2007) report that perceived usefulness and perceived ease of use positively impact upon consumer willingness to make M-Payments at instore electronic points-of-sale (EPOS). Kim et al. (2010) suggest that consumers' are willing to make an M-Payment if they find the system to be useful for their transaction needs. Schierz et al. (2010) note that ease of use is even more important for M-Payment services, as they compete with established payment services.

Interestingly, few of the previous M-Commerce studies have been conducted in a European context. However, this is largely because European countries have been a laggard when compared to Asian countries with respect to the adoption of $\mathrm{M}$ Commerce. In fact, M-Payment services have largely failed to entice or convince European consumers, and several M-Payment companies/initiatives in the EU have already been abandoned (Dahlberg and Oorni 2007; Mallat 2007). Thus, while several M-Commerce adoption studies exist in the literature, few of these specifically focus on M-Payments, few are European based, and none of these studies are sufficiently comprehensive with respect to the inclusion of previously established, empirically tested, constructs from both E-Commerce and M-Commerce literature. Gaining a better understanding of European consumers' perceptions of using Smart Phones to make M- 
Payments is thus required, in order to develop M-Payment services for successful adoption by consumers (Dahlberg and Oorni 2007). Dahlberg et al. (2008) state:

“... we believe that more theory based empirical research is needed to enhance the current understanding of the M-Payment services markets. ... to improve the quality and relevance of M-Payment research, we also recommend that researchers collect more empirical data backed by guiding theories." (Dahlberg et al. 2008 p.178)

This paper makes a number of contributions to both theory and practice. Firstly, it contributes a conceptual model for exploring consumer's perceptions of M-Payments. It explores variables that hadn't previously been investigated pertaining to their impact on consumer's willingness to make an M-Payment. It adopts and combines several factors identified and empirically tested in previous E-Commerce and M-Commerce studies, namely; trust, personal innovativeness, perceived ease of use, perceived usefulness, and mobile self-efficacy, in order to investigate their impact on Irish consumers' willingness to use Smart Phones to make M-Payments. An understanding of these factors can have significant implications for M-Payment service providers in developing more appropriate M-Payment services and applications, guiding M-Payment deployment strategies and information and marketing campaigns. Furthermore, it informs mobile vendors of how to create more positive relationships with consumers in the M-Commerce environment.

From the perspective of theory development, adding to the existing knowledge in the field of M-Commerce about the factors influencing adoption of M-Payment systems, especially in a European context represents a significant contribution through enabling researchers develop richer theoretical models that better explain adoption behaviours. Furthermore, this study serves as an important starting point from which 
researchers can engage in future comparative cross-cultural studies of M-Payment adoption in European and non-European markets.

The remainder of this paper is structured as follows. The next section discusses conceptualisation of the theoretical model and identifies 4 research hypotheses. Following this, methodological design and data analysis is presented. The subsequent section presents the results of the study and the research model evaluation. The theoretical implications of the findings and the challenges for practitioners are then discussed, with concluding remarks and study limitations bringing the paper to a close.

\section{Theoretical model conceptualisation and research hypothesis}

M-Payments are a critical enabler of the true commercial value of the Smart Phone (Andreev et al. 2011; O'Reilly and Duane 2010). Although, literature proposes three fundamental models for handling M-Payments: 1) mobile network operator led, 2) bank and financial institution led, and 3) third party led, with numerous variations/combinations of these being possible (Turner 2009); in practice, an accepted M-Payment model to facilitate the widespread adoption of M-Payments still remains elusive. Ultimately, consumers will play a key role in determining the "winning" model, as consumer buy-in for any proposed M-Payment model is critical. Thus, the enormous potential of Smart Phones for M-Commerce is entirely contingent on consumers' willingness to make M-Payments using Smart Phones.

However, consumer acceptance, or willingness to make an M-Payment, is the greatest barrier to M-Payment adoption, which is very much influenced by their assessment of the risk involved (Mallat 2007). Thus, it is of great concern that there is considerable evidence that users perceive significant risks and uncertainty in interacting with vendors through mobile devices (Im et al. 2008). Viehland and Yoong Leong 
(2010) contend that in order for M-Payments to succeed, consumers must perceive them as being useful and easy to use, but most importantly, secure and safe to use.

Viehland and Yoong Leong (2010) and Dahlberg et al. (2007) report that both perceived usefulness and perceived ease of use, positively impact consumer willingness to make an M-Payment at retail points-of-sale. Therefore, perceived ease of use, perceived usefulness, and perceived payment reliability, which incorporate a consumer's perception of the security and perceived safety of making an M-Payment using a Smart Phone, are three important issues for consumers if they are to adopt MPayment services. Chen et al. (2011) tested TAM in their recent study on Smart Phone acceptance, and reveal that MSE also plays a positive role on perceived ease of use.

Personal innovativeness, or an individual's willingness to try out new technology, also appears to have a significant impact on the adoption of new technologies (Agarwal and Prasad 1998). While Agarwal and Prasad (1998) examined the moderating effects of personal innovativeness on intention to adopt, Gupta et al. (2011) reveal that personal innovativeness has a direct positive impact on willingness to use mobile location-based services (LBS). Thus, personal innovativeness may also impact upon an individual's willingness to make an M-Payment.

Several studies (e.g. Jarvenpaa et al. 2000; Gefen et al. 2003; Verhagen et al. 2006; Chen and Barnes 2007) reveal that trust is a significant determinant in influencing consumers' E-Commerce transactions, as a lack of trust discourages consumers from making a transaction. More recently, a number of studies (Siau et al. 2004; Xu and Gutierrez 2006; Mallat 2007) indicate that trust is also a significant determinant of consumers' decisions to engage in M-Commerce transactional tasks. Lin and Wang (2006) also found that trust has a positive impact on consumer loyalty and satisfaction 
towards M-Commerce. Thus, trust is an important component of any model seeking to explain a consumers' willingness to make an M-Payment.

Thus, having reflected on prior research, this study examines the impact of trust (Trust), personal innovativeness (PI), perceived ease of use (PEU), perceived usefulness (PU), and mobile self-efficacy (MSE), in order to develop a model explaining consumers' willingness to use Smart Phones to make M-Payments. The following discussion describes the development of the constructs used in this study.

\subsection{Trust}

A user's feelings of trust toward an online service is an important determinant in considering it's usage (Chau et al. 2007; Roca et al. 2008). Sanchez-Franco and Rondan-Cataluña (2011) believe trust is the most important antecedent. Lie et al. (2010) found that trust is crucial in M-Commerce, given the anonymous buyer-seller interactions and lack of formal contractual agreements, while Varnali and Toker (2009) consider a lack of trust as a major obstacle in the adoption of mobile services. Similarly, Mallat (2007) found that trust in vendors and mobile network operators (MNOs) is essential to reduce consumers perceived risks of M-Payments.

We therefore present our first hypothesis:

Hypothesis 1: Consumers' trust positively impacts upon their willingness to make M-Payments using Smart Phones.

However, trust is a multi-dimensional construct, studied in a variety of social science disciplines (Bhattacherjee 2002), and with a multitude of definitions (Hsu et al. 2007). Thus, Roca et al. (2008) suggest that by considering trust as a reflection in different dimensions, a better understanding of trust as a construct can be achieved. Thus, a thorough review of the literature reveals 7 manifest variables of trust (Table 1). 
Table 1. Trust measures for this study

\begin{tabular}{ll}
\hline Element & Literature \\
\hline Perceived Security Control & (Chou et al. 2004); (Dewan and Chen 2005);(Roca et al. \\
& 2008). \\
\hline Perceived Privacy Control & (Roca et al. 2008); (Wu and Tsang 2008). \\
\hline Perceived Integrity & (Cheung and Lee 2003; Flavián and Guinalíu \\
& 2006);(Roca et al. 2008); (Lorenzo-Romero et al. 2011). \\
\hline Perceived Ethical & (Chiu et al. 2009); (Yang et al. 2009); (Chen et al. 2011); \\
Commitment & (Sanchez-Franco and Rondan-Cataluña 2011). \\
\hline Perceived Competence & (Flavián and Guinalíu 2006); (Sanchez-Franco and \\
& Rondan-Cataluña 2011). \\
\hline Perceived Governance & (Cheung and Lee 2003); (Cleff 2007); (Sanchez-Franco \\
& and Rondan-Cataluña 2011). \\
\hline Perceived Independence of & (Cheung and Lee 2003); (Cleff 2007) (Sanchez-Franco \\
Regulatory Authority & and Rondan-Cataluña 2011). \\
\hline
\end{tabular}

Shortcomings in security controls reduce consumer's trust in M-Payment systems and hinder the emergence of these systems (Chou et al. 2004; Dewan and Chen 2005). When online vendors have implemented the appropriate security mechanisms, consumers perceive online purchasing as being safe (Roca et al. 2008). Perceived privacy control is also a critical factor in consumers' acceptance of online services, as consumers are reluctant to share any personal or financial information with online vendors because they feel that these vendors could use this information for unintended purposes. In order to protect customers' privacy, organisations must protect all the personal information which they collect either directly or indirectly from other organisations (Wu and Tsang 2008).

If individuals perceive a vendor to be honest or of high integrity, their intention to use the electronic channel will be higher (Roca et al. 2008). Roca et al. (2008) suggest individuals will have greater trust in an electronic channel if they are less concerned about unauthorised use of, or illegal access to, their data by third parties. Privacy policies (Flavián and Guinalíu 2006) and Social Media feedback mechanisms (Lorenzo-Romero et al. 2011) convey signals of online vendor integrity. Privacy 
policies (Chen et al. 2011) and guarantee policies (Chiu et al. 2009), which are associated with the ethical perception of Web vendors in terms of their ability to handle sensitive consumer information, and consumers' rights and interests, play a significant role in influencing consumer trust.

Yang et al. (2009) reveal higher levels of perceived ethical commitment also increases trust, and heavily influences online purchasing decisions. Flavián and Guinalíu (2006) and Sanchez-Franco and Rondan-Cataluña (2011) suggest perceived competence is also particularly important for an online vendor as they have to persuade the consumer that in addition to being honest and reliable, they also have the technical, financial and human resources required to complete the transaction successfully.

Consumer trust in vendor compliance with legislation and the existence of an independent regulatory authority to protect and regulate transactions and data, are essential to reduce consumers perceived risks of making an M-Payment (Cleff 2007). Regulatory safeguards promote consumer confidence in engaging in online transactions, and online vendors should prioritise their support for regulation (Sanchez-Franco and Rondan-Cataluña 2011). It is important that an independent objective regulator and the government should play central roles in establishing legislation and standards of service (Cheung and Lee 2003). Online vendors can minimise uncertainty by clearly displaying their rules and all the necessary legal aspects and seals of approval (e.g. VeriSign, TRUSTe) (Sanchez-Franco and Rondan-Cataluña 2011).

\subsection{Personal innovativeness}

Agarwal and Prasad (1998) validated a construct for the domain of information technology called "personal innovativeness in the domain of IT" (PIIT) for characterising technology adoption, which is defined as "the willingness of an individual to try out any new information technology". Personal innovativeness is 
specific to an individual (Agarwal and Prasad 1998), and it is the same as innate innovativeness, which is part of an individual's personality (Im et al. 2003). Innate innovativeness had a positive impact on driving consumer acceptance of mobile marketing (Bauer et al. 2005), and these first adopters often become a source of opinion on innovations for their peers (Barmecha 2011). Similarly, Gupta et al. (2011) suggest that personal innovativeness had a significant impact on intention to use mobile location-based services. In addition, Lu et al. (2005) report that PIIT is an important stimulus influencing perceptions of wireless Internet services via mobile technology, and that PITT significantly influences both perceived usefulness (PU) and perceived ease of use (PEU), with the latter being particularly affected. Thus, in the context of this study, we propose that:

Hypothesis 2a: Personal innovativeness positively impacts upon consumers' perceptions of the ease of use of a Smart Phone to make an M-Payment.

Hypothesis 2b: Personal innovativeness positively impacts upon consumers' willingness to make M-Payments using Smart Phones.

Hypothesis 2c: Personal innovativeness positively impacts upon consumers' perceptions of the usefulness of a Smart Phone to make an M-Payment.

\subsection{Perceived ease of use and perceived usefulness}

Ease of use has been documented in the extant literature as being an imminent acceptance driver of mobile applications (Schierz et al. 2010). A review of the literature revealed a small number of researchers employed TAM to explore M-Payments. Viehland and Yoong Leong (2010) and Dahlberg et al. (2007) examined perceived usefulness and perceived ease of use on consumer willingness to use M-Payment services at retail points-of-sale and report that most consumers consider M-Payments easy to use and useful. Schierz et al. (2010) note that ease of use becomes even more 
important for M-Payment services, which compete with established payment solutions, and thus need to provide benefits when it comes to ease of use. Therefore, one of the main reasons for the slow diffusion of M-Payments in particular, could be a failure in understanding the perception among consumers of the ease of use of making MPayments using Smart Phones. Thus, having explored extant literature on perceived ease of use and perceived usefulness, we propose:

Hypothesis 3a: Perceived ease of use will have a positive effect on consumers' willingness to use Smart Phones to make M-Payments.

Hypothesis 3b: Perceived usefulness will have a positive effect on consumers' willingness to use Smart Phones to make M-Payments.

\section{$2.4 \quad$ Perceived mobile self-efficacy}

Self-efficacy refers to one's belief in what they can do with the capability or skills they have (Hsu et al. 2011), or in their capability to perform a particular behaviour (Lai 2008). According to Bandura (1994), the nature and scope of perceived self-efficacy undergoes several changes as new and emerging competency demands arise, which require further development of self-efficacy to function successfully. Evidence of this exists in the literature as measures for perceived self-efficacy have emerged for computer self-efficacy, Internet self-efficacy, and in recent times, mobile self-efficacy. Computer self-efficacy measures one's confidence in mastering a new technology or software with a certain degree of confidence (Lai 2008). Internet self-efficacy specifically relates to usage of E-Commerce, as it requires a skill set beyond simple computer use (Keith et al. 2011). Young Hoon et al. (2009) note that E-Commerce transaction self-efficacy, as a situation-specific self-efficacy, positively influences a consumer 's online purchase intention. Evidence of this may be emerging in recent MCommerce literature, as Lee et al. (2011) report that mobile self-efficacy has a 
significant influence on attitude towards consumers' willingness to adopt mobile advertising. Furthermore, Igbaria and Iivari (1995) suggest that computer self-efficacy had a "strong direct effect on perceived ease of use"(p.587), underlining its importance in the decision to use technology. Evidence of this also exists in the M-Commerce literature as Chen et al. (2011) tested TAM in their recent study on Smart Phone acceptance, and conclude that mobile self-efficacy played a positive role on Perceived Ease of Use. However, irrespective of whichever form of technology-related selfefficacy arises in the literature, knowledge and confidence play an important role (Khorrami-Arani 2001) as do judgments of what one can do with the skill-set one possesses (Bandura 1994). Thus, in this context we propose:

Hypothesis 4a: Mobile self-efficacy positively impacts upon consumers' perceived ease of use in using Smart Phones to make M-Payments.

Hypothesis 4b: Mobile self-efficacy positively impacts upon consumers' willingness to use Smart Phones to make an M-Payment.

According to Bandura (1986), a self-efficacy instrument must assess the specific skills needed for performing an activity. Given that over 300,000 mobile applications (Apps.) have been developed in the last three years (MobiThinking 2011), and this study does not exclusively focus on mobile self-efficacy, it is simply not possible at this time to create a self-efficacy measure capable of precisely assessing the specific skills needed to use each Application (App). Therefore, the researchers utilised a grounded approach in this regard, adopting the approach recommended by Vispoel and Chen (1989) who advised researchers to develop new, or significantly revise existing, measures for each study of self-efficacy. Thus, a number of indicators of self-efficacy were developed for use in this study through adoption and extension of extant literature. These items are presented in the indicator descriptor table (Table 2). 
Therefore, through a detailed review of the literature, four hypotheses emerged, enabling the generation of a research model, presented in Figure 1, to investigate consumers' willingness to use Smart Phones to make M-Payments.

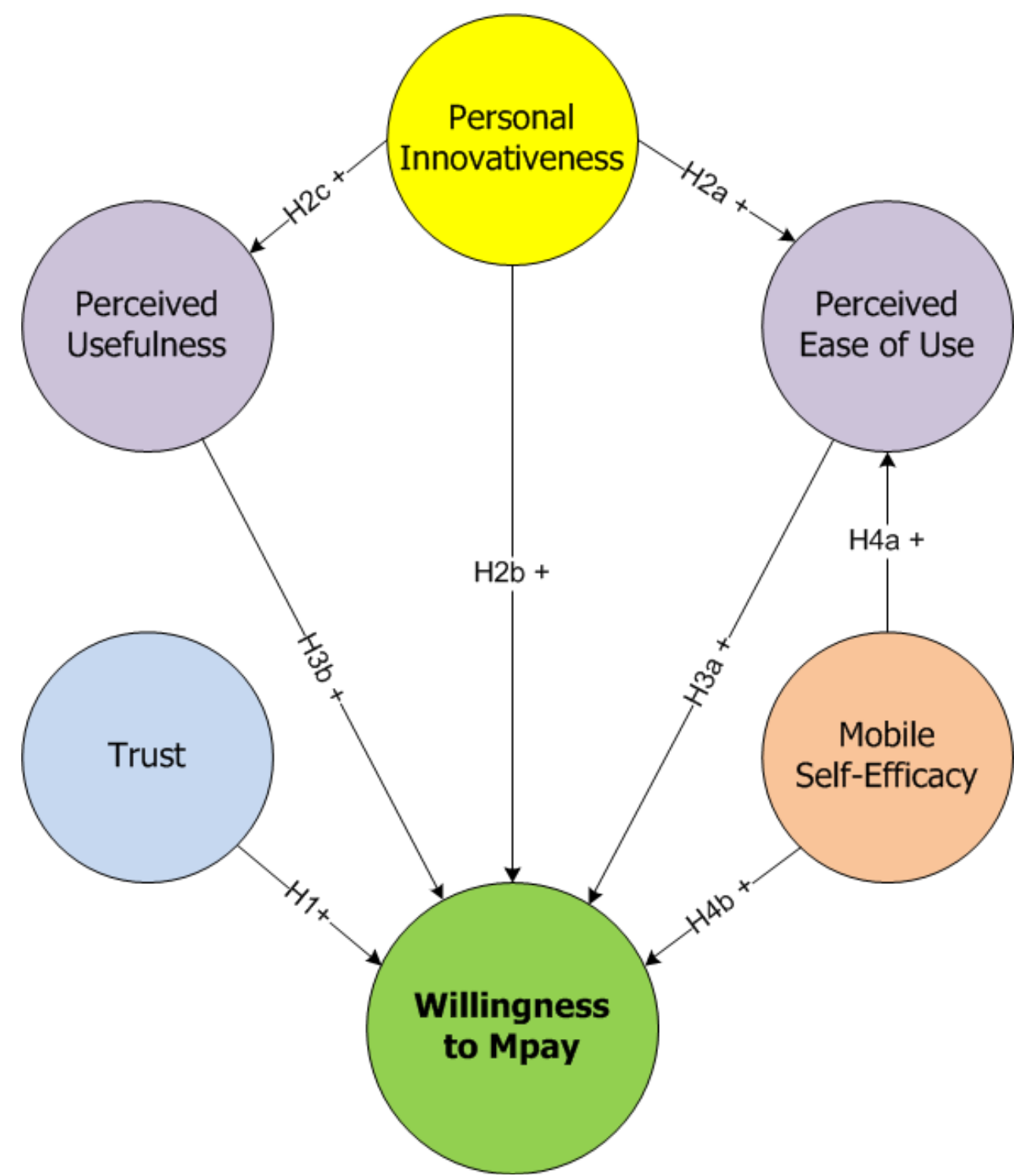

Figure 1. A Smart Phone M-Payment Model

\subsection{Willingness to Make an M-Payment (M-Pay)}

Most measures of willingness to make an electronic payment, and in some cases an M-

Payment (e.g.) Viehland and Yoong Leong (2010), reflect on previous measures established in the marketing literature that simply measure "price sensitivity". The purpose of Willingness to make M-Payment in this study is not to study price sensitivity 
with respect to mobile purchases, but rather consumers' willingness to use the "MPayment Process" as previously referred to in Section 1. However, one must recognise that the M-Payment market is still in its infancy, and no single M-Payment model has emerged as the de-facto and may not do so for a considerable period of time given the lucrative market that exists and that rival services will continue to compete with each other and invest significant amounts of money in acquisitions and research (Ondrus and Lyytinen 2011). Thus, different mobile vendors adopt different M-Payment models, and consequently consumers currently interact with multiple M-Payment models, and will continue to do so for the foreseeable future.

Ondrus and Lyytinen (2011) suggest that "it is still premature to conclude any certain scenarios. The upcoming announcements of the new players will probably give more insights into the variability of future scenarios for mobile payments". Measurement of Willingness to Make an M-Payment in this study embraces this idea, and reflects consumers' willingness to make an M-Payment using all 4 current M-Payment models in the marketplace (MNO driven (e.g. O2), Third-Party Driven (e.g. PayPal), Credit Card Company Driven (e.g. Visa), and Domestic Bank Driven (Laser Debit Card similar to Maestro) driven. Ondrus et al. (2009) posit "that there is a lack of multiperspective research that is needed to obtain a holistic view of payment system adoption and evolution. In addition, we need to conduct research that follows more than just one perspective at a time". Thus, this research develops a new measure for willingness to make an M-Payment to reflect the current state of research. This measure reflects the M-Payment models identified by Ondrus et al. (2009) of M-Maestro, PostFinance, and Verified by Visa. 
Table 2. Indicators description

\begin{tabular}{|c|c|c|c|}
\hline Construct & Item & Survey Statement & Adapted From \\
\hline \multirow{3}{*}{$\begin{array}{l}\text { Perceived Ease } \\
\text { of Use } \\
(P E U)\end{array}$} & PEEASY & Overall, I find SMMS easy to use. & \multirow{3}{*}{$\begin{array}{l}\text { (Luarn and Lin } \\
\text { 2005; Chau et al. } \\
\text { 2007) }\end{array}$} \\
\hline & PEKNOW & $\begin{array}{l}\text { Use of SMMS does not require a lot of } \\
\text { knowledge. }\end{array}$ & \\
\hline & PETECH & $\begin{array}{l}\text { Use of SMMS does not require a lot of technical } \\
\text { skills. }\end{array}$ & \\
\hline \multirow{4}{*}{$\begin{array}{l}\text { Perceived } \\
\text { Usefulness } \\
(P U)\end{array}$} & PUACCOMP & $\begin{array}{l}\text { Use of SMMS can decrease the time required for } \\
\text { my activities. }\end{array}$ & \multirow{4}{*}{$\begin{array}{l}\text { (Agarwal and } \\
\text { Prasad 1998; } \\
\text { Venkatesh 2000) }\end{array}$} \\
\hline & PUPROD & $\begin{array}{l}\text { Use of SMMS can increase my output for the } \\
\text { same amount of effort. }\end{array}$ & \\
\hline & PUEFFWA & $\begin{array}{l}\text { Use of SMMS improves the effectiveness of my } \\
\text { work activities. }\end{array}$ & \\
\hline & PUEFFPA & $\begin{array}{l}\text { Use of SMMS improves the effectiveness of my } \\
\text { personal activities. }\end{array}$ & \\
\hline \multirow{3}{*}{$\begin{array}{l}\text { Personal } \\
\text { Innovativeness } \\
(P I)\end{array}$} & PIEXPERI & I like to experiment with new SMMS. & \multirow{3}{*}{$\begin{array}{l}\text { (Agarwal and } \\
\text { Prasad 1998; } \\
\text { Bauer et al. } \\
\text { 2005; Gupta et } \\
\text { al. 2011) } \\
\text { (Barmecha } \\
\text { 2011) }\end{array}$} \\
\hline & PIFIRST & $\begin{array}{l}\text { Among my peers, I am usually the first to try out } \\
\text { new SMMS. }\end{array}$ & \\
\hline & PIPEEROPIN & My peers highly rate my opinion of SMMS. & \\
\hline \multirow{7}{*}{$\begin{array}{l}\text { Mobile Self- } \\
\text { Efficacy (MSE) }\end{array}$} & MSESOCACT & I feel confident using SMMS for social activities. & \multirow{7}{*}{$\begin{array}{l}\text { (Murphy et al. } \\
\text { 1989; Agarwal } \\
\text { and Prasad 1998; } \\
\text { Young Hoon et } \\
\text { al. 2009) }\end{array}$} \\
\hline & MSEMOVMUS & $\begin{array}{l}\text { I feel confident using SMMS to access online } \\
\text { movies and music }\end{array}$ & \\
\hline & MSETVMED & $\begin{array}{l}\text { I feel confident using SMMS to access television } \\
\text { news media. }\end{array}$ & \\
\hline & MSEPRINTMED & $\begin{array}{l}\text { I feel confident using SMMS to access print news } \\
\text { media. }\end{array}$ & \\
\hline & MSETVPROG & $\begin{array}{l}\text { I feel confident using SMMS to watch television } \\
\text { programmes. }\end{array}$ & \\
\hline & MSEGAMES & $\begin{array}{l}\text { I feel confident using my Smart Phone to access } \\
\text { gaming services }\end{array}$ & \\
\hline & MSESOCMED & $\begin{array}{l}\text { I feel confident using my Smart Phone for social } \\
\text { media }\end{array}$ & \\
\hline \multirow[t]{7}{*}{$\begin{array}{l}\text { Trust } \\
\text { (Trust) }\end{array}$} & LFROBUST & $\begin{array}{l}\text { Legal frameworks for SMMS provision are } \\
\text { sufficiently robust to protect consumers. }\end{array}$ & \multirow{7}{*}{$\begin{array}{l}\text { (Cheung and Lee } \\
\text { 2003; Chau et al. } \\
\text { 2007) }\end{array}$} \\
\hline & PCEXPERT & $\begin{array}{l}\text { I believe that SMMS providers have sufficient } \\
\text { expertise and resources to provide these services. }\end{array}$ & \\
\hline & PECETHIC & $\begin{array}{l}\text { I believe that SMMS providers will act ethically } \\
\text { when capturing, retaining, processing, and } \\
\text { managing my personal data. }\end{array}$ & \\
\hline & PINTHONEST & $\begin{array}{l}\text { I believe that SMMS providers act honestly in } \\
\text { dealing with consumers. }\end{array}$ & \\
\hline & PPCCONFPRIV & $\begin{array}{l}\text { I am confident in the privacy controls of SMMS } \\
\text { providers. }\end{array}$ & \\
\hline & PSCPERSDATA & $\begin{array}{l}\text { I believe that all SMMS providers implement } \\
\text { adequate security measures to secure my personal } \\
\text { data. }\end{array}$ & \\
\hline & REGAUTH & $\begin{array}{l}\text { Regulatory bodies for SMMS provision are } \\
\text { sufficiently authoritative to regulate SMMS } \\
\text { providers. }\end{array}$ & \\
\hline \multirow{4}{*}{$\begin{array}{l}\text { Willingness to } \\
\text { Make an } M- \\
\text { Payment } \\
\text { (WMPay) }\end{array}$} & PPRMNO & $\begin{array}{l}\text { I consider it safe to make an M-Payment through } \\
\text { my mobile network operator when using SMMS. }\end{array}$ & \multirow{4}{*}{ Self created } \\
\hline & PPRSAFE3RD & $\begin{array}{l}\text { I consider it safe to make an M-Payment through a } \\
\text { 3rd party payment company when using SMMS. }\end{array}$ & \\
\hline & PPRSAFECC & $\begin{array}{l}\text { I consider it safe to make an M-Payment with my } \\
\text { credit card when using SMMS. }\end{array}$ & \\
\hline & PPRSAFELASER & $\begin{array}{l}\text { I consider it safe to make an M-Payment with my } \\
\text { laser card when using SMMS. }\end{array}$ & \\
\hline
\end{tabular}




\section{Method}

\subsection{Design}

An online survey was developed to operationalise the research model. Following, an initial iteration of the survey as per Hair et al. (2006), the authors pre-tested the survey with Smart Phone "experts" (active Smart Phone owners and users) in order to assess the semantic content of construct items. The authors retained those items that best fitted and reflected the definitions of the constructs, a process that facilitated the refinement and streamlining of the items included in this survey. In order to minimise non-response bias we utilised some of the principles purported by Vicente and Reiss (2010) pertaining to designing web distributed questionnaires. Through a review and analysis of the extant literature, they illustrated that by applying such principles, the risk of non-response bias is greatly reduced. Therefore, we employed those principles in this study; screen design layout, avoided lengthy questions, included an intermittent progress indicator and applied a radio button format. In dealing with the danger of common method bias we began by utilising the principles of Podsakoff et al. (2003). We obtained measures of the predictor and criterion variables from multiple sources (further, construct reliability tests were conducted (Section 4.2.1) within the measurement PLS models validation). Furthermore, we ensured the questionnaire was anonymous and avoided the use of complicated and ambiguous wording.

The next phase of this research posted the survey online using a web based survey administration tool located at www.SurveyMonkey.com. The target population of users were informed of this survey by posting a survey notification and weblink on an Irish Smart Phone users' discussion group located at www.Boards.ie. This online group had 928 members with average monthly user activity rates of $42 \%$. Responses 
were collected throughout June 2010. Irish Smart Phone users were selected as the target population as there had been no research conducted on M-Payments in Ireland to our knowledge, despite Ireland having one of the largest rates of mobile phone usage in Europe per head of population, with a $117.3 \%$ penetration rate as of December 2010 (ComReg 2011). In fact, 1 out of every 2 mobile phones sold in Ireland in 2010 were Smart Phones (Vodafone-Ireland 2010).

In operationalising the constructs, indicators arising from the literature were either wholly adopted or revised in order to develop questions for data collection. In addition, the researchers created a number of new measures to measure consumers' willingness to make an M-Payment (WMPay). Table 2 presents these indicators, their associated questions, and their sources in the literature where applicable.

\subsection{Data analysis}

The study employed structural equation modelling, a model-testing tool, for data analysis and hypotheses testing. Choosing the PLS (SEM) approach, which uses component-based estimation, is appropriate since it allows simultaneous exploration of both the measurement and the structural models. In addition, the PLS approach compared to covariance-based SEM, allows for testing of the relationships in the model with less restrictive requirements. Another reason for choosing PLS is that this tool is considered to be appropriate for testing theories at earlier stages of development (Fornell and Bookstein 1982) as in the context of this study. This technique facilitates the exploration of two models, the measurement (outer) model, relating the measurement variables (MV) to their latent variables (LV), and the structural (inner) model, relating the LVs to each other (Chatelin et al. 2002; Tenenhaus et al. 2005; Diamantopoulos 2006 ). 


\section{Results}

\subsection{Data statistics}

One month after posting the survey notification and weblink to the Irish Smart Phone users' discussion group located at www.Boards.ie, the authors closed the survey collection mechanism located at www.SurveyMonkey.com. Analysis of the online survey hosted on Survey Monkey, revealed that 141 of the 928 Irish Smart Phone Users' online discussion group invited to participate in the study, had responded. However, only 82 of the responses were deemed valid, as 59 respondents had failed to complete the entire survey, primarily citing the high number of questions in the survey as the reason for abandoning the survey before completion. Despite this, respondents originated from twelve of Ireland's 26 counties including large cities such as Dublin, Cork, and Waterford, which when combined accounted for $68 \%$ of respondents. As shown in Table 3, the demographic attributes of a respondent to this survey is a person:

- between the ages of 30-50 years,

- living in a large Irish city,

- educated to a post-graduate level, and,

- in full-time employment earning $€ 40,000$ to $€ 80,000$ per annum.

Table 3. Respondent demographic profile

\begin{tabular}{|c|c|c|c|c|c|c|c|c|c|c|c|}
\hline Income & $\begin{array}{c}\text { No. of } \\
\text { Respondents }\end{array}$ & $\begin{array}{c}\% \text { of } \\
\text { Respondents }\end{array}$ & Age & $\begin{array}{c}\text { No. of } \\
\text { Respondents }\end{array}$ & $\begin{array}{c}\% \text { of } \\
\text { Respondents }\end{array}$ & $\begin{array}{l}\text { SMMS Spend } \\
\text { Per Month }\end{array}$ & $\begin{array}{c}\text { No. of } \\
\text { Respondents }\end{array}$ & $\begin{array}{c}\% \text { of } \\
\text { Respondents }\end{array}$ & Education & $\begin{array}{c}\text { No. of } \\
\text { Respondents }\end{array}$ & $\begin{array}{c}\text { \% of } \\
\text { Respondents }\end{array}$ \\
\hline Prefer not to say & $\begin{array}{r}6 \\
\end{array}$ & \begin{tabular}{|r|}
$7.32 \%$ \\
\end{tabular} & $18-21$ yrs & $\begin{array}{r}3 \\
\end{array}$ & $3.66 \%$ & $<€ 1.00$ & 46 & $56.10 \%$ & Primary Level & 0 & $0.00 \%$ \\
\hline$<€ 20,000$ & 10 & $12.20 \%$ & $22-25$ yrs & 8 & $9.76 \%$ & $€ 1.00-€ 2.00$ & 9 & $10.98 \%$ & 2nd Level & 4 & $4.88 \%$ \\
\hline$€ 20,000-30,000$ & 7 & $8.54 \%$ & 26-30 yrs & 12 & $14.63 \%$ & $€ 2.01-€ 5.00$ & 13 & $15.85 \%$ & 3rd Level Under-Graduate & 23 & $28.05 \%$ \\
\hline$€ 30,001-40,000$ & 7 & $8.54 \%$ & $31-35$ yrs & 17 & $20.73 \%$ & $€ 5.01-€ 10.00$ & 6 & $7.32 \%$ & 3rd Level Post-Graduate & 46 & $56.10 \%$ \\
\hline$€ 40,001-50,000$ & 10 & $12.20 \%$ & $36-40 \mathrm{yrs}$ & 26 & $31.71 \%$ & $€ 10.01-€ 20.00$ & 3 & $3.66 \%$ & \multirow{5}{*}{ 4th Level (PhD, Post-doc) } & \multirow[t]{5}{*}{9} & \multirow[t]{5}{*}{$10.98 \%$} \\
\hline$€ 50,001-60,000$ & 14 & $17.07 \%$ & $41-50 \mathrm{yrs}$ & 14 & $17.07 \%$ & $€ 20.01-€ 30.00$ & 2 & $2.44 \%$ & & & \\
\hline$€ 60,001-70,000$ & 6 & $7.32 \%$ & $51-60$ yrs & 1 & $1.22 \%$ & $€ 30.01-€ 50.00$ & 1 & $1.22 \%$ & & & \\
\hline$€ 70,001-80,000$ & 8 & $9.76 \%$ & \multirow{2}{*}{$>60$ years } & \multirow[t]{2}{*}{1} & \multirow[t]{2}{*}{$1.22 \%$} & \multirow[t]{2}{*}{$>€ 50.00$} & \multirow[t]{2}{*}{2} & \multirow[t]{2}{*}{$2.44 \%$} & & & \\
\hline$>€ 80,000$ & 14 & $17.07 \%$ & & & & & & & & & \\
\hline Totals & 82 & $100 \%$ & & 82 & $100 \%$ & & 82 & $100 \%$ & & 82 & $100 \%$ \\
\hline
\end{tabular}


$62 \%$ of respondents used the Internet for more than two hours per day. $83 \%$ of respondents accessed the Internet using their Smart Phone for less than one hour per day. $90 \%$ of respondents talked on their Smart Phone for less than an hour per day, while $40 \%$ sent more than ten SMS per day. $78 \%$ of respondents never sent an MMS, and 56\% never sent email from their Smart Phone. 27\% of respondents spent between $€ 1-5$ per month on SMMS, while $15 \%$ spent between $€ 5-50$ per month. This suggests that the typical profile of a respondent in this survey is a person who:

- accesses the Internet via their Smart Phone for less than an hour per day,

- talks on their Smart Phone for less than an hour per day,

- regularly uses their Smart Phone for SMS, but rarely for MMS or email, and,

- use their Smart Phone to purchase Smart Mobile Media Services (SMMS).

Respondents indicated that they perceived SMMS to be easy to use, and not requiring a lot of knowledge or technical skills. Interestingly, respondents preferred MPayment model is one facilitated through an application provided by banks, whereby the payment would simply be debited automatically from their own bank account, while using their existing Mobile Network Operator (MNO) to pay for products/services was also rated highly. Respondents displayed significant levels of concern regarding perceived privacy control, the authority and independence of regulatory bodies, and in the robustness of the legislative frameworks governing M-Commerce.

\subsection{Model evaluation}

PLS models with reflective constructs have a well-defined and widely accepted validity technique. The list of assessment criteria was first summarised and proposed by Chin (1998). Researchers from different research fields accepted and further adopted these criteria (e.g. Gefen et al. 2000; Tenenhaus et al. 2005; Henseler et al. 2009). The 
evaluation process of the PLS path model involves two steps. Step 1 necessitates the testing of the quality of the measurement (outer) models. If Step 1 is successful and latent constructs are reliable and valid, Step 2, which necessitates the assessment of the structural (inner) model, should be conducted (Henseler et al. 2009).

The authors employed SmartPLS 2.0 M3 for the PLS model assessments. The online survey produced a sample size of 82 complete and valid responses. Although 82 is a relatively small sample size, it is sufficient to get reliable PLS results. Firstly, it meets a generally accepted "10 times" rule of thumb, that defines the minimum sample size as 10 times the most complex relationships in the research model (Chin 1998). The most complex construct in the research model has four predictors of Willingness to MPay, necessitating a minimum respondent sample size of 40 .

\subsubsection{Assessment of measurement models}

Reliability. The first criterion in the assessment of measurement models is reliability, which traditionally refers to internal consistency reliability and indicator reliability. Internal consistency reliability corresponds to testing either Cronbach's $\alpha$, which indicates an estimation of the reliability assuming that all items are equally reliable, or composite reliability, where different item loadings are taken into account. Although those two reliability measures differ, either of them may be used. Table 4 shows that both parameters have high values (all values are above 0.912 ), as the requirement value is only required to be above 0.7 in the early stages of research, and above $0.8-0.9$ in the advanced stages (Henseler et al. 2009).

Individual reliability of the indicators relies on the expectation that latent variable variance should explain at least $50 \%$ of the indicator. In other words, loadings of manifest variables should not be less than 0.707 (Chin 1998; Gefen et al. 2000; Henseler et al. 2009). Figure 2 demonstrates that the magnitude of all indicators is 
higher than the required value of 0.707 . Based on the two tests, the authors can conclude that all indicators are reliable.

Table 4. Internal consistency reliability test

\begin{tabular}{ccc}
\hline Construct & Composite Reliability & Cronbach's Alpha \\
\hline MSE & 0.939 & 0.923 \\
PI & 0.958 & 0.934 \\
PU & 0.938 & 0.912 \\
PeU & 0.944 & 0.913 \\
Trust & 0.944 & 0.930 \\
WMPay & 0.967 & 0.954 \\
\hline
\end{tabular}

Validity. Convergent validity and discriminant validity examine the validity of four reflective constructs. The first column in Table 5 shows that the average variance extracted (AVE) for all constructs is higher than 0.5, which indicates sufficient convergent validity, and means that each latent variable explains more than $50 \%$ of their indicator variance on average. Discriminant validity refers to the appropriate patterns of the inter indicators of a construct and other constructs. First, the variance of a construct should be aligned more with their own indicators than with other constructs. For this purpose, we compared construct cross-correlation and the square root of each construct's AVE. Table 5 illustrates that all constructs have sufficient discriminant validity since the square root of each latent construct's AVE (values on the diagonal) is much larger than the correlation of the specific construct with any other reflective construct in our research model.

The authors also tested discriminant validity with a cross-loading test. Table 6 presents results of the test and demonstrates that an indicator of any specific construct has a higher loading on its own construct than on any other constructs. The results of the tests show that manifest variables (indicators) presented in the research model are reliable and valid. 


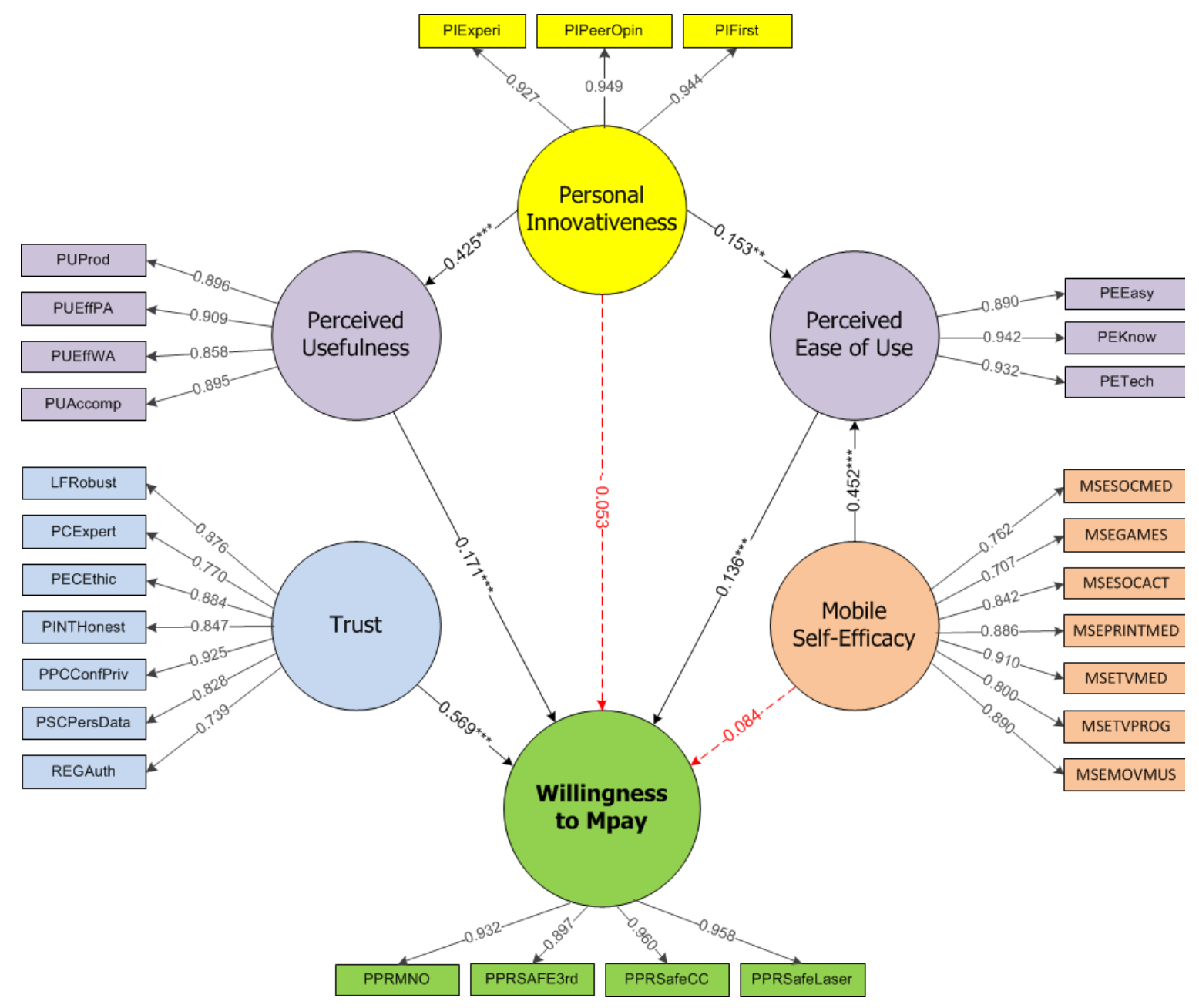

Figure 2. PLS results of measurement and structural models

Table 5. Construct cross-correlation matrix and AVE analyses

\begin{tabular}{llllllll}
\hline AVE & Construct & MSE & PI & PU & PeU & Trust & WMPay \\
\hline 0.689 & MSE & $\mathbf{0 . 8 3 0}$ & & & & & \\
0.883 & PI & 0.632 & $\mathbf{0 . 9 4 0}$ & & & & \\
0.792 & PU & 0.395 & 0.425 & $\mathbf{0 . 8 9 0}$ & & & \\
0.850 & PeU & 0.548 & 0.438 & 0.363 & $\mathbf{0 . 9 2 2}$ & & \\
0.707 & Trust & 0.380 & 0.373 & 0.318 & 0.363 & $\mathbf{0 . 8 4 1}$ & \\
0.878 & WMPay & 0.409 & 0.345 & 0.412 & 0.428 & 0.685 & $\mathbf{0 . 9 3 7}$ \\
\hline
\end{tabular}


Table 6. Cross loadings

\begin{tabular}{|c|c|c|c|c|c|c|c|}
\hline Construct & Items & MSE & PI & PU & PeU & Trust & WMPay \\
\hline \multirow[t]{7}{*}{ MSI } & MSESOCMED & 0.752 & 0.538 & 0.294 & 0.386 & 0.235 & 0.234 \\
\hline & MSEGAMES & 0.707 & 0.493 & 0.423 & 0.352 & 0.326 & 0.325 \\
\hline & SMMDSOCACTIV & 0.842 & 0.513 & 0.292 & 0.510 & 0.387 & 0.379 \\
\hline & MSESOCACT & 0.886 & 0.484 & 0.360 & 0.558 & 0.396 & 0.433 \\
\hline & MSETVMED & 0.911 & 0.558 & 0.287 & 0.432 & 0.331 & 0.358 \\
\hline & MSETVPROG & 0.800 & 0.496 & 0.339 & 0.371 & 0.241 & 0.297 \\
\hline & MSEMOVMUS & 0.890 & 0.614 & 0.316 & 0.515 & 0.253 & 0.306 \\
\hline \multirow[t]{3}{*}{ PI } & PIEXPERI & 0.609 & 0.928 & 0.377 & 0.360 & 0.297 & 0.244 \\
\hline & PIFIRST & 0.581 & 0.949 & 0.426 & 0.398 & 0.350 & 0.338 \\
\hline & PIPEEROPIN & 0.596 & 0.944 & 0.393 & 0.466 & 0.396 & 0.376 \\
\hline \multirow[t]{4}{*}{ PU } & PUPROD & 0.303 & 0.385 & 0.896 & 0.373 & 0.219 & 0.326 \\
\hline & PUEFFPA & 0.346 & 0.393 & 0.909 & 0.287 & 0.376 & 0.435 \\
\hline & PUEFFWA & 0.406 & 0.356 & 0.858 & 0.380 & 0.166 & 0.339 \\
\hline & PUACCOMP & 0.353 & 0.378 & 0.895 & 0.263 & 0.351 & 0.356 \\
\hline \multirow[t]{3}{*}{$\mathrm{PeU}$} & PEEASY & 0.588 & 0.508 & 0.318 & 0.891 & 0.367 & 0.412 \\
\hline & PEKNOW & 0.448 & 0.350 & 0.348 & 0.942 & 0.303 & 0.394 \\
\hline & PETECH & 0.450 & 0.317 & 0.339 & 0.932 & 0.322 & 0.367 \\
\hline \multirow[t]{7}{*}{ Trust } & PCEXPERT & 0.271 & 0.290 & 0.289 & 0.353 & 0.770 & 0.576 \\
\hline & PECETHIC & 0.250 & 0.237 & 0.162 & 0.319 & 0.884 & 0.549 \\
\hline & PINTHONEST & 0.417 & 0.425 & 0.324 & 0.256 & 0.847 & 0.540 \\
\hline & PPCCONFPRIV & 0.328 & 0.279 & 0.263 & 0.324 & 0.925 & 0.626 \\
\hline & LFROBUST & 0.285 & 0.289 & 0.260 & 0.283 & 0.876 & 0.539 \\
\hline & PSCPERSDATA & 0.390 & 0.392 & 0.302 & 0.354 & 0.828 & 0.716 \\
\hline & REGAUTH & 0.273 & 0.260 & 0.265 & 0.207 & 0.739 & 0.392 \\
\hline \multirow[t]{4}{*}{ WMPay } & PPRMNO & 0.362 & 0.313 & 0.393 & 0.415 & 0.674 & 0.932 \\
\hline & PPRSAFE3RD & 0.383 & 0.352 & 0.307 & 0.345 & 0.582 & 0.897 \\
\hline & PPRSAFECC & 0.401 & 0.324 & 0.389 & 0.459 & 0.651 & 0.960 \\
\hline & PPRSAFELASER & 0.388 & 0.307 & 0.449 & 0.378 & 0.655 & 0.958 \\
\hline
\end{tabular}

\subsection{Assessment of the structural model}

In assessing the explanatory and predictive power of the structural model, the authors employed the recommendations included in extant research (Chin 1998; Gefen et al. 2000; Chatelin et al. 2002; Andreev et al. 2009; Henseler et al. 2009).

Explanatory power. Figure 3 presents an overview of the structural model evaluation results. The central criterion for evaluating the structural model is the level of explained variance of the dependent construct Willingness to MPay, for which the $\mathrm{R}^{2}$ was 0.534 . 
Thus, the model explained $53.4 \%$ of the construct's variance. The variance of the construct was explained at the moderate level consistent with Chin's (1998) criteria. $\mathrm{R}^{2}$ values of $0.67,0.33$, or 0.19 for endogenous latent variables are substantial, moderate, or weak respectively (Chin 1998 p.323).

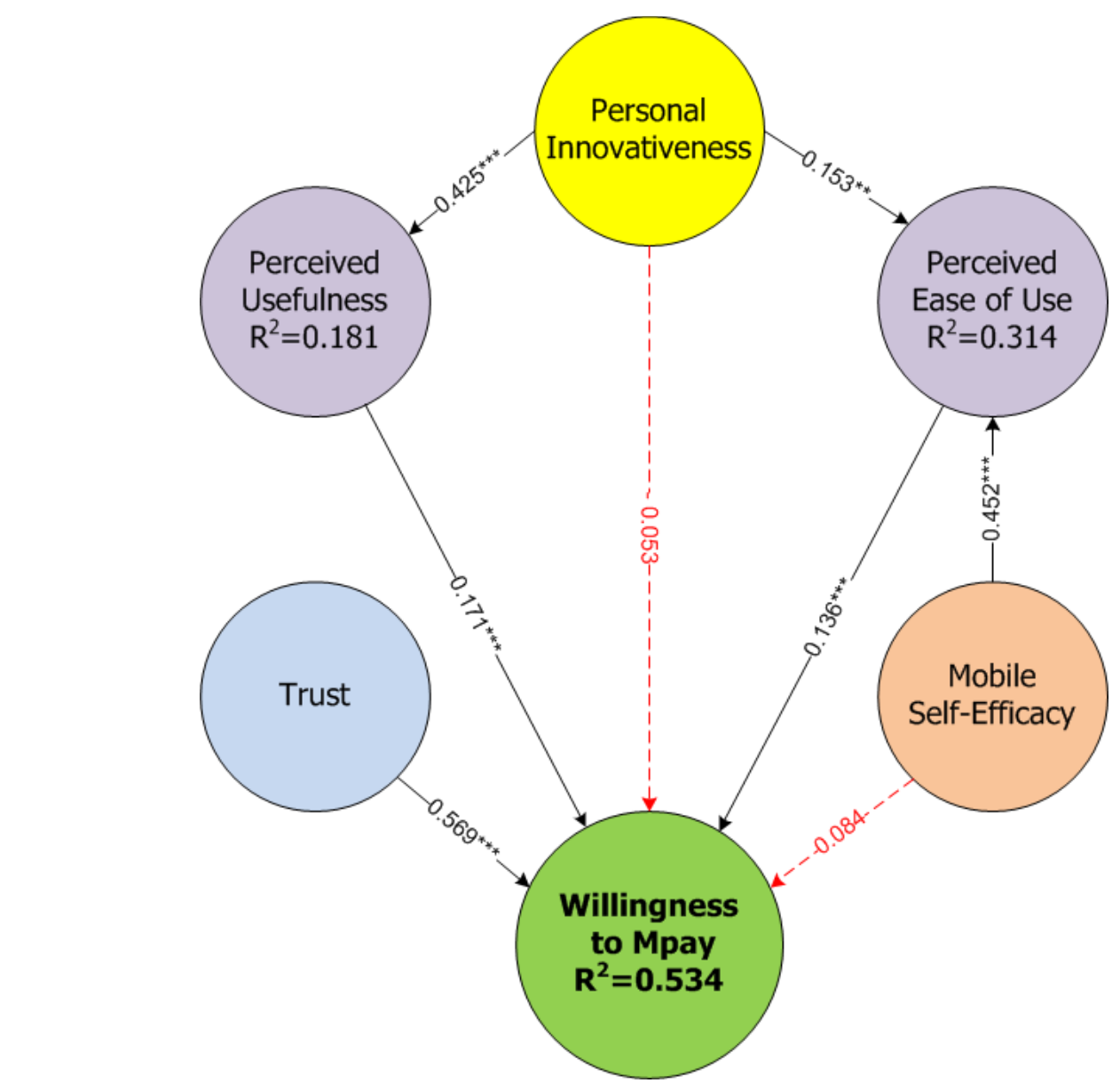

$* * * \mathrm{p}<0.001, * * \mathrm{p}<0.01$. (based on $\mathrm{t}\left(299^{1}\right)$, two-tailed test). $\mathrm{t}$-value $(0.001 ; 299)=3.315 ; \mathrm{t}(0.01 ; 399)=2.58 ; \mathrm{t}(0.05 ; 299)=1.96$

Figure 3. Structural model evaluation

In addition, within the research model, Mobile Self-Efficacy and Personal Innovativeness explain $31.4 \%$ of the Perceived Ease of Use variance, while the variance of Perceived Usefulness is explained by Personal Innovativeness (18.1\%).

The study explored changes in $\mathrm{R}^{2}$ to investigate the substantive impact of each independent construct on the dependent constructs, carrying out the effect size technique by re-running three PLS estimations, excluding in each run, one of the

\footnotetext{
${ }^{1}$ The t-test for each path coefficient was conducted with n-1 degrees of freedom, where $\mathrm{n}$ is a number of subsample repetitions in bootstrapping procedure. 300 repetitions were chosen resulting 299 is degrees of freedom.
} 
explaining latent constructs. Table 7 represents a summary of the quantitative results of the effect size test. Chin (1998) proposed to use the effect size $\mathrm{f}^{2}$ of PLS constructs, which similar to Cohen's implementation for multiple regression might be small $\left(\mathrm{f}^{2}=\right.$ $0.02)$, medium $\left(f^{2}=0.15\right)$, and large $\left(f^{2}=0.35\right)$.

Table 7. Effect size test

\begin{tabular}{lllll}
\hline Construct & $\mathbf{R}^{\mathbf{2}}$ incl & $\mathbf{R}^{\mathbf{2}}$ excl & $\mathbf{f}^{\mathbf{2}}$ & Effect \\
\hline Trust & 0.534 & 0.280 & 0.545 & Large \\
PU & 0.534 & 0.512 & 0.047 & Small \\
PeU & 0.534 & 0.522 & 0.026 & Small \\
PI & 0.534 & 0.531 & 0.006 & - \\
MSI & 0.534 & 0.531 & 0.006 & - \\
\hline
\end{tabular}

The results of the effect size (Table 7) show that while Perceived Ease of Use and Perceived Usefulness have small effects (with $\mathrm{f}^{2}$ equals to 0.026 and 0.047 respectively), on consumers' willingness to use a Smart Phone to make an M-Payment, Trust has a large effect with magnitude of $\mathrm{f}^{2}=0.545$.

Predictive power. Employing the bootstrapping re-sampling technique, using the SmartPLS software, enabled a test for the statistical significance of the path coefficients. The evaluation of the structural model shows that all path coefficients were highly statistically significant (Figure 3). The study found that, Trust (H1 supported with $\beta=0.569$ and $p<0.001$ ), Perceived Usefulness (H3b supported with $\beta=0.171$ and $p<$ 0.001), and Perceived Ease of Use (H3a supported with $\beta=0.136$ and $p<0.001$ ) positively affect consumers' willingness to use a Smart Phone to make an M-Payment.

Personal Innovativeness positively affected both Perceived Ease of Use (H1a supported with $\beta=0.153$ and $\mathrm{p}<0.01$ ), and Perceived Usefulness (H1c supported with $\beta=0.425$ and $p<0.001)$.

Mobile Self-Efficacy positively affected Perceived Ease of Use (H4a supported with $\beta=0.452$ and $p<0.001)$. However, impacts of both Mobile Self-Efficacy and 
Personal Innovativeness on consumers' willingness to use a Smart Phone to make an M-

Payment were found to be statistically insignificant ( $\mathrm{H} 2 \mathrm{~b}$ and $\mathrm{H} 4 \mathrm{~b}$ are not supported).

The authors performed the Stone and Geisser $\mathrm{Q}^{2}$ test for the evaluation of the predictive relevance of the structural model. Chin (1998) stated that $\mathrm{Q}^{2}$ reflects an index of goodness of reconstruction by model and parameter estimations. A positive $\mathrm{Q}^{2}$ provides evidence that the omitted observations were well-reconstructed and that predictive relevance is achieved, while a negative $\mathrm{Q}^{2}$ reflects absence of predictive relevance. Table 8 shows that all values of $\mathrm{Q}^{2}$ were greater than zero, indicating predictive relevance for the endogenous constructs of the research model.

Table 8. Blindfolding test for predictive relevance

\begin{tabular}{llll}
\hline Construct & $\sum \mathrm{SO}$ & $\sum \mathrm{SE}$ & $\mathrm{Q}^{2}$ \\
\hline PU & 324 & 279.10 & 0.14 \\
PeU & 243 & 183.17 & 0.25 \\
WMPay & 324 & 172.12 & 0.47 \\
\hline
\end{tabular}

\section{Discussion and conclusions}

By exploring consumers' willingness to use Smart Phones to make M-Payments, this paper makes a number of significant theoretical and practical contributions of value to both researchers and practitioners. Both of these will now be discussed.

\subsection{Theoretical Contribution}

Consumer intention to use Smart Phones for transactional services and M-Payment is of scientific and practical interest. In this study we sought to extend the theoretical knowledge of M-Payment adoption, by developing a model explaining consumers' willingness to use Smart Phones to make M-Payments. Indeed, this paper makes a number of theoretical contributions to the M-Payments literature. Firstly, it contributes a conceptual model for exploring consumer's perceptions of M-Payments and in 
developing same several factors which hadn't been previously been applied to the MPayments domain were incorporated. The study adopted and empirically tested a number of constructs previously recognised in extant literature as being influential in consumers' decision to adopt mobile advertising, mobile marketing, location-based services, mobile banking, M-Commerce, and E-Commerce in general. These constructs have previously not been used in a single study focusing on the willingness of European consumers to use Smart Phones to make M-Payments. Four main hypotheses (divided into a number of sub hypothesis) were proposed and the results provide strong support for the theoretical predictions. Several implications for theory were identified from these results.

Viehland and Yoong Leong (2010) state that perceived ease of use (PEU) and trust impact on consumers' willingness to make an M-Payment using a Smart Phone. However, both factors are treated the same with no differentiation being made between these factors. The results from this study extend extant research by clearly differentiating between these factors in terms of impact, illustrating that trust is the critical factor in explaining consumers' willingness to make an M-Payment using Smart Phones, while the impact of perceived ease of use (PEU) is significantly less. This is significant as it contradicts the findings of Schierz et al. (2010) which suggest that ease of use is very important for M-Payment services, which compete with established payment solutions, and thus need to provide benefits when it comes to ease of use. Our findings show that although perceived ease of use (PEU) is important, it is not actually a key factor in explaining the slow diffu sion of M-Payments using Smart Phones.

While Lee et al. (2011) found that mobile self-efficacy (MSE) had a significant impact on consumers' willingness to adopt mobile advertising, the results of this study clearly illustrate that MSE has only a small impact on consumers' willingness to use a 
Smart Phone to make an M-Payment. However, the results show that MSE does have a significant impact on perceived ease of use (PEU). This is consistent with the findings of Chen et al. (2011). These results may indicate that while consumers are convinced of the ease of use of Smart Mobile Media Services (SMMS), they still harbour suspicion and significant concerns about making an M-Payment using a Smart Phone. The authors strongly recommend that future studies should develop and test more extensive measures of MSE as it relates to M-Payments, given the vast number of SMMS available to consumers, and the difficulties their inherent differences pose in measuring MSE in an M-Commerce environment.

Agarwal and Prasad (1998) validated "personal innovativeness in the domain of IT" (PIIT) for characterising technology adoption. Previous studies of the impact of personal innovativeness on mobile marketing (Bauer et al. 2005) and mobile locationbased services (Gupta et al. 2011) indicated that it influences the adoption of both types of SMMS. This study reveals however, that although personal innovativeness (PI) strongly influences consumers' perceptions of the usefulness of a Smart Phone to make an M-Payment, personal innovativeness has very little direct impact on consumers' willingness to use a Smart Phone to make an M-Payment. Personal innovativeness also has a small impact on consumers' perceived ease of use (PEU) of a Smart Phone to make an M-Payment. Thus, while our study does not reflect the findings of Gupta et al. (2011), further research could consider the moderating effects of PI, similar to Agarwal and Prasad (1998), rather than the direct impact on consumers' willingness to make MPayments. As previously stated, M-Payments are still in their infancy in Europe, and clearly established mechanisms have yet to emerge. Thus, future studies could reflect upon Im et al.'s (2003) differentiation of innate PI and actual PI, and measure actual adoption of M-Payments. 


\subsection{Implications for Practice and Future Research}

Smart Phones present organisations with a significant amount of commercial opportunities. For commercial organisations to avail of such opportunities, an understanding of consumer's perceptions of Smart Phones is of paramount importance. Yet, both the practitioner and academic literature, particularly in a European context, are immature in explaining consumer adoption of M-Payments using Smart Phones.

The findings of this study present conclusive evidence that trust is the single most important factor influencing consumers' willingness to use Smart Phones to make M-Payments. Perceived usefulness and perceived ease of use do influence the payment decision, but they are less important, while mobile self-efficacy and personal innovativeness have almost no impact. It is clear then, that irrespective of individuals' displaying high levels of personal innovativeness, or mobile self-efficacy, and irrespective of whether the SMMS is perceived to be useful and easy to use, consumers will not make M-Payments unless they are convinced of the payment reliability of the Smart Phone M-Payment system.

Our analysis illustrates that consumer's perceptions of privacy controls, legal frameworks, and the regulation of these frameworks are integral parts of trust in an MCommerce environment, and critical for consumers' willingness to use Smart Phones to make M-Payments. Similar to the study of consumer acceptance of online services by Roca et al. (2008), perceived privacy control emerges in this study as a critical factor in consumers' willingness to use Smart Phones to make an M-Payment. These findings are very important for practitioners, and a number of suggestions can be purported through interpreting our findings. Firstly, commercial entities need to communicate to consumers that they implement policies, and employ the latest technologies to protect the privacy and data of consumers. For government and commercial entities who wish 
to develop an M-Payment culture, the authors suggest that these entities review their legal frameworks, with the goal being to ensure that they are adequate to protect consumers. Furthermore, consumers' perceptions of regulatory bodies having sufficient powers to take action against service providers who do not adhere to such frameworks, is an issue requiring further detailed research.

The authors advise that it is possible that perceived ease of use (PEU) may become a more important mitigating factor as M-Payment services become more established, and consumers' have a greater choice of which M-Payment model to actually use, because the preferred M-Payment model for Irish consumers is one facilitated through an application provided by banks, whereby the payment would simply be debited automatically from their own bank account. Thus, it is possible that perceived ease of use (PEU) may in future actually influence consumers' choice of which M-Payment model to use, rather than their decision to use a Smart Phone to make an M-Payment. The authors therefore recommend that as M-Payment models mature and consumers' have a greater choice of which M-Payment models to adopt, that further studies investigate perceived ease of use (PEU) between the offerings in more detail.

Although this paper reveals important findings for the development of theoretical models and practitioners alike, nevertheless, there are a number of limitations to this study. The sample size represents a limitation of the study, with findings based on 82 respondents participating in the study. Therefore, further research needs to be conducted to re-examine the model with a larger sample size. Furthermore, the majority of respondents to this survey were between 30-50 years of age; thus, future research could consider a multi-group analysis to see if the model is invariantly consistent (e.g. across gender and age groups). This research also is limited to Smart Phone consumers in Ireland, thus a wider European study is required. The authors are 
currently completing further research to investigate the explanatory power of the model for different socio-demographic groups and for specific products/services. Such research may provide further insight on the impact of perceived ease of use on MPayments. Furthermore, steps are underway to further test the model in the context of evaluating consumer adoption of the various M-Payments models available using Smart Phones.

\section{References}

Agarwal, R. and J. Prasad (1998). "A Conceptual and Operational Definition of Personal Innovativeness in the Domain of Information Technology." Information Systems Research 9(2): 204-215.

Andreev, P., A. Duane and P. O'Reilly (2011). Conceptualising Consumer Perceptions of Contactless M-Payments through Smart Phones. International Federation for Information Processing: IFIP WG8.2.

Andreev, P., T. Heart, H. Maoz and N. Pliskin (2009). Validating Formative Partial Least Squares (PLS) Models: Methodological Review and Empirical Illustration. ICIS 2009 Proceedings.

Bandura, A. (1986). Social foundations of thought and action: A social cognitive theory. Englewood Cliffs, NJ, Prentice-Hall.

Bandura, A., Ed. (1994). Self-efficacy. Encyclopedia of Human Behavior New York, Academic Press.

Barmecha, M. (2011). Commerce for the Digital Consumer. Building Tomorrow's Enterprise, InfoSys.

Barutcu, S. (2008). "Consumers' Attitudes Towards Mobile Marketing and Mobile Commerce in Consumer Markets." Ege Academic Review 8(1): 15-32.

Bauer, H. H., S. J. Barnes, T. Reichardt and M. M. Neumann (2005). "Driving Consumer Acceptance of Mobile Marketing: A Theoretical Framework and Empirical Study." Journal of Electronic Commerce Research 6(3): 181--192.

Bhattacherjee, A. (2002). "Individual trust in online firms: Scale development and initial test." Journal of Management Information Systems 19(1): 211-241.

Chatelin, Y. M., V. E. Vinzi and M. Tenenhaus (2002). "State-of-Art on PLS Path Modeling through the Available Software." Les Cahiers de Recherche, 764, Groupe HEC. 
Chau, P. Y. K., P. J. H. Hu, B. L. P. Lee and A. K. K. Au (2007). "Examining customers' trust in online vendors and their dropout decisions: An empirical study." Electronic Commerce Research and Applications 6(2): 171-182.

Chen, K., J. V. Chen and D. C. Yen (2011). "Dimensions of self-efficacy in the study of smart phone acceptance." Computer Standards \& Interfaces 33(4): 422-431.

Chen, Y. H. and S. Barnes (2007). "Initial Trust and Online Buyer Behaviour." Industrial Management and Data Systems 107(1): 21--36.

Cheung, C. M. K. and M. K. O. Lee (2003). An integrative model of consumer trust in internet shopping. ECIS Proceedings.

Chin, W. W. (1998). The Partial Least Squares Approach to Structural Equation Modeling. Modern Methods for Business Research M. G.E. Mahwah, New Jersey, Lawrence Erlbaum Associates: 295--336.

Chiu, C.-M., H.-Y. Lin, S.-Y. Sun and M.-H. Hsu (2009). "Understanding customers' loyalty intentions towards online shopping: an integration of technology acceptance model and fairness theory." Behaviour \& Information Technology 28(4): 347-360.

Chou, Y., C. Lee and J. Chung (2004). "Understanding M-Commerce Payment Systems through the Analytic Hierarchy Process." Journal of Business Research 57(12): 1423-1430 .

Chung, N. and S. J. Kwon (2009). "Effect of trust level on mobile banking satisfaction: a multi-group analysis of information system success instruments." Behavior and Information Technology 28(6): 549-562.

Cleff, E. B. (2007). "Implementing the Legal Criteria of Meaningful Consent in the Concept of Mobile Advertising." Computer Law and Security Report 23(3): 262--269.

ComReg (2011). Commission for Communications Regulation Quarterly Key Data Report Data as of Q1 2011. Quarterly Key Data Reports. C. f. Communications: 77.

Dahlberg, T., N. Mallat, J. Ondrus and A. Zmijewska (2008). "Past, Present and Future of Mobile Payments Research: A Literature Review." Electronic Commerce Research and Applications 7(2): 165--181.

Dahlberg, T. and A. Oorni (2007). Understanding Changes in Consumer Payment Habits - Do Mobile Payments and Electronic Invoices Attract Consumers? HICSS: 50.

Davis, F. D. (1989). "Perceived Usefulness, Perceived Ease of Use, and User Acceptance of Information Technology." MIS Quarterly 13(3): 319--340.

Dewan, S. G. and L. Chen (2005). "Mobile Payment Adoption in the USA: A Crossindustry, Cross-platform Solution." Journal of Information Privacy \& Security 1(2): 4--28. 
Diamantopoulos, A. (2006 ). "The error term in formative measurement models: interpretation and modeling implications." J Model Manage 1 (1): 7-17.

Dinez, E., J. Albuquerque and A. Cernez (2011). Mobile Money and Payment: a literature review based on academic and practitioner-oriented publications (2001-2011). Proceedings of SIG GlobDev Fourth Annual Workshop, Shanghai, China.

Egger, F. N. and D. Abrazhevich (2001). "Security \& Trust: Taking Care of the Human Factor." Electronic Payment Systems Observatory Newsletter 9. Retrieved 19th of July, 2012, from http://www.ecommuse.com/en/articles.

Enterprise Ireland (2011). "M-Commerce and M-Payments." Retrieved 5th July, 2011, from http://www.ebusinesslive.ie/newsletter/Story/4/1828/ob.html/277.

Flavián, C. and M. Guinalíu (2006). "Consumer trust, perceived security and privacy policy: Three basic elements of loyalty to a web site." Industrial Management \& Data Systems 106(5): 601-620.

Fornell, C. and F. L. Bookstein (1982). "Two Structural Equation Models: LISREL and PLS Applied to Consumer Exit-Voice Theory." Journal of Marketing research 19(4): 440--452.

Gao, J. and A. Küpper (2006). "Emerging Technologies for Mobile Commerce." Journal of Theoretical and Applied Electronic Commerce Research 1(2).

Gefen, D., E. Karahanna and D. W. Straub (2003). "Trust and TAM in Online Shopping: An Integrated Model." Mis Quarterly 27(1): 51--90.

Gefen, D., D. W. Straub and M.-C. Boudreau (2000). "Structural Equation Modeling and Regression: Guidelines for Research and Practice." CAIS 4(7): 1--70.

Goldman, S. M. (2010). "Transformers." Journal of Consumer Marketing 27(5): 469473.

Gupta, S., H. Xu and X. Zhang (2011). "Balancing privacy concerns in the adoption of Location-Based Services: an empirical analysis." International Journal of Electronic Business 9(1/2): 118-137.

Hair, J. F., W. C. Jr. Black, B. J. Babin, R. E. Anderson and R. L. Tatham (2006). Multivariate Data Analysis, New Jersey: Prentice Hall.

Henseler, J., C. M. Ringle and R. R. Sinkovics (2009). "The Use of Partial Least Squares Path Modeling in International Marketing." Advances in International Marketing 20(2009): 277--319.

Higgs, B. (2008). Strategy Notes: On Location. Marketing(Dec/Jan): 82--82.

Hsu, H. Y. S. and S. Kulviwat (2006). "An Integrative Framework of Technology Acceptance Model and Personalisation in Mobile Commerce." International Journal of Technology Marketing 1(4): 393--410. 
Hsu, M. H., C. M. Chang and C. H. Yen (2011). "Exploring the antecedents of trust in virtual communities." Behaviour \& Information Technology.

Hsu, M. H., L. Ju, C. H. Yen and C. M. Chang (2007). "Knowledge sharing behavior in virtual communities: The relationship between trust, self-efficacy, and outcome expectations." International Journal of Human-Computer Studies 65: 153-169.

Igbaria, M. and J. Iivari (1995). "The effects of self-efficacy on computer usage." Omega 23(6): 587-605.

Im, I., Y. Kim and H. J. Han (2008). "The Effects of Perceived Risk and Technology Type on Users' Acceptance of Technologies." Information \& Management 45(1): 1-9.

Im, S., B. L. Bayus and C. H. Mason (2003). "An Empirical Study of Innate Consumer Innovativeness, Personal Characteristics, and New-Product Adoption Behavior." Journal of the Academy of Marketing Science 31(1): 61-73.

Jarvenpaa, S. L., N. Tractinsky and M. Vitale (2000). "Consumer Trust in an Internet Store." Information technology and management 1(1): 45--71.

Jayasingh, S. and U. Eze (2009). "An Empirical Analysis of Consumer Behavioural Intention Towards Mobile Coupons in Malaysia." International Journal of Business and Information 4(2): 221-242.

Juniper Research (2010). "Press Release: Mobile Payments Market to Quadruple by 2014 , reaching $\$ 630 \mathrm{bn}$ in value, although still only accounting for around 5\% of ecommerce retail sales." Retrieved 5th July, 2011, from http://juniperresearch.com/viewpressrelease.php?pr=173.

Keith, M. J., Babb Jr. J.S., C. P. Furner and A. Abdullat (2011). "The Role of Mobile Self-Efficacy in the Adoption of Location-Based Applications: An iPhone Experiment." Proceedings of the 44th Hawaii International Conference on System Sciences.

Khorrami-Arani, O. (2001). "Researching computer self-efficacy." International Education Journal 2(4): 17-25.

Kim, C., M. Mirusmonov and I. Lee (2010). "An empirical examination of factors influencing the intention to use mobile payment." Computers in Human Behavior 26(3): 310-322.

Kim, Y. and P. Zhang (2009). "Individual Users' Adoption of Smart Phone Services." SIGHCI 2009 Proceedings: 19.

Lai, M. L. (2008). "Technology readiness, internet self-efficacy and computing experience of professional accounting students." Campus-Wide Information Systems 25(1): 18-29. 
Lee, C.-C., M.-C. Hsieh and H.-C. Huang (2011). "The Influence of Mobile Selfefficacy on Attitude towards Mobile Advertising." AISS: Advances in Information Sciences and Service Sciences 3(3): 100-108.

Leppäniemi, M. and H. Karjaluoto (2005). "Factors Influencing Consumers' Willingness to Accept Mobile Advertising: A Conceptual Model." International Journal of Mobile Communications 3(3): 197--213.

Lie, T., W. Fang and P. A. Pavlou (2010). "The Triangular Relationship among Vendor, User and Technology on Trust in Mobile Commerce: A Cross Cultural Comparison." from www.ntpu.edu.tw/ads/doc/paper\%20lee.doc

Lin, H. H. and Y. S. Wang (2006). "An Examination of the Determinants of Customer Loyalty in Mobile Commerce Contexts." Information \& Management 43(3): 271--282.

Lorenzo-Romero, C., E. Constantinides and M.-D.-C. Alarcón-del-Amo (2011). "Consumer adoption of social networking sites: implications for theory and practice." Journal of Research in Interactive Marketing 5(2/3).

Lu, J., J. E. Yao and C.-S. Yu (2005). "Personal innovativeness, social influences and adoption of wireless Internet services via mobile technology." Journal of Strategic Information Systems 14(3): 245-268.

Luarn, P. and H. H. Lin (2005). "Toward an understanding of the behavioral intention to use mobile banking." Computers in Human Behavior 21(6): 873-891.

Mallat, N. (2007). "Exploring Consumer Adoption of Mobile Payments - A Qualitative Study." The Journal of Strategic Information Systems 16(4): 413--432.

Matthews, T., J. Pierce and J. Tang (2009). "No Smart Phone is an Island: The Impact of Places, Situations, and Other Devices on Smart Phone Use." Research Report RJ10452, IBM.

MobiThinking (2011). "Global Mobile Statistics 2011." Retrieved 5th July, 2011, from http://mobithinking.com/stats-corner/global-mobile-statistics-2011-all-quality-mobilemarketing-research-mobile-web-stats-su

Murphy, C. A., D. Coover and S. V. Owen (1989). "Development and validation of the computer self-efficacy scale." Educational and Psychological Measurement(49): 893899.

O'Reilly, P. and A. Duane (2010). Smart Mobile Media Services (SMMS). The 8th International Conference on advances in mobile computing and multimedia, Paris, France.

Ondrus, J. and K. Lyytinen (2011). "Mobile Payments Market: Towards Another Clash of the Titans". Proceedings of the Tenth International Conference of Mobile Business (ICMB). 
Ondrus, J., K. Lyytinen and Y. Pigneur (2009). "Why Mobile Payments Fail? Towards a Dynamic and Multi-Perspective Explanation". In the Proceedings of the 42nd Hawaii International Conference on System Sciences, Waikoloa, Hawaii.

Podsakoff, P., S. B. MacKenzie, J. Y. Lee and N. Podsakoff (2003). "Common Method Biases in Behavioral Research: A Critical Review of the Literature and Recommended Remedies." Journal of Applied Psychology 88(5): 879-903.

Rao, L. (2011). "Google Survey: 39 Percent Of Smartphone Owners Use Their Devices In The Bathroom." Retrieved May 2d, 2011, from http://techcrunch.com/2011/04/26/google-survey-39-percent-of-smartphone-ownersuse-their-device-in-the-bathroom/.

Roca, J. C., J. J. Garcia and J. J. de la Vega (2008). "The importance of perceived trust, security and privacy in online trading systems." Information Management \& Computer Security 17(2): 96-113.

Sanchez-Franco, M. and F. J. Rondan-Cataluña (2011). "Connection between customer emotions and relationship quality in online music services." Behaviour \& Information Technology 29(6): 633-651.

Schaettgen, N. and K. Taga (2010). "An acronym-free primer on mobile payments." Retrieved 5th July, 2010, from http://adlittle.nl/uploads/tx_extprism/ADL_PRISM_2_2010_m-payment.pdf.

Schierz, P. G., O. Schilke and B. W. Wirtz (2010). "Understanding Consumer Acceptance of Mobile Payment Services: An Empirical Analysis." Electronic Commerce Research and Applications 9(3): 209--216.

Siau, K., H. Sheng, F. Nah and S. Davis (2004). "A Qualitative Investigation on Consumer Trust in Mobile Commerce." International Journal of Electronic Business 2(3): 283--300.

Skeldon, P. (2011). "Growing Consumer Demand for Mobile Prompts Massive Investment in New Multichannel Platforms as Retailers Look to Integrate Everything." Retrieved 5th July, 2011, from http://www.internetretailing.net/2011/06/growingconsumer-demand-for-mobile-prompts-massive-investment-in-new-multichannelplatforms-as-retailers-look-to-integrate-everything/.

Tenenhaus, M., V. E. Vinzi, Y.-M. Chatelin and C. Lauro (2005). "PLS Path Modeling." Computational Statistics \& Data Analysis 48(1): 159--205.

Turner, A. (2009). "M-Payment Models: Starting to Look Good, Payments Cards and Mobile." May/June, from http://www.paymentscardsandmobile.com.

Varnali, K. and A. Toker (2009). "Mobile marketing research: the state of the art. ." International Journal of Information Management 30: 144-151.

Varshney, U. and R. Vetter (2002). "Mobile Commerce: Framework, Applications and Networking Support." Mobile Networks and Applications 7(3): 185--198. 
Venkatesh, V. (2000). "Determinants of Perceived Ease of Use: Integrating Control, Intrinsic Motivation, and Emotion into the Technology Acceptance Model." Information Systems Research 11(4): 342-365.

Verhagen, T., S. Meents and Y. H. Tan (2006). "Perceived Risk and Trust Associated with Purchasing at Electronic Marketplaces." European Journal of Information Systems 15(6): 542--555.

Vicente, P. and E. Reiss (2010). "Using Questionnaire Design to Fight Nonresponse Bias in Web Surveys." Social Science Computer Review 28: 251-267.

Viehland, D. and R. S. Yoong Leong (2010). "Consumer Willingness to Use and Pay for Mobile Payment Services." International Journal of Principles and Applications of Information Science and Technology 3(1): 34-46.

Vodafone-Ireland (2010). "Preliminary Results Announcement for the quarter ended 31st December 2010." Retrieved 20th of April, 2012, from http://www.vodafone.ie/aboutus/media/press/show/BAU012194.shtml;jsessionid=2D83 NSWpRGTlzZh7LCxCGpytHRgCJ2x6D3Q70hTLyc5gMJYKNt2f! 138711505 !2036466758?date $=\mathrm{Thu}+\mathrm{Feb}+03+14 \% 3 \mathrm{~A} 52 \% 3 \mathrm{~A} 00+\mathrm{GMT}+2011$.

Wei, R., H. Xiaoming and J. Pan (2010). "Examining User Behavioral Response to SMS Ads: Implications for the Evolution of the Mobile Phone as a Bona-Fide Medium." Telematics and Informatics 27(1): 32--41.

Wu, J. J. and A. S. L. Tsang (2008). "Factors affecting members' trust belief and behaviour intention in virtual communities." Behaviour \& Information Technology 27(2): 115-125.

Xu, G. and J. A. Gutierrez (2006). "An Exploratory Study of Killer Applications and Critical Success Factors in M-Commerce." Journal of Electronic Commerce in Organizations 4(3): 63--79.

Xu, H., T. Hock-Hai, B. C. Y. Tan and R. Agarwal (2010). "The Role of Push-Pull Technology in Privacy Calculus: The Case of Location-Based Services." Journal of Management Information Systems 26(3): 137-176.

Yang, M. H., N. Chandlress, B. Lin and H.-Y. Chao (2009). "The Effect of Perceived Ethical Performance of Shopping Websites on Consumer Trust." Journal of Computer Information Systems 50(1): 15-24.

Young Hoon, K., D. J. Kim and H. Yujong (2009). "Exploring Online Transaction SelfEfficacy in Trust Building in B2C E-Commerce." Journal of Organizational \& End User Computing 21(1): 37-59.

Zhong, J. (2009). "A Comparison of Mobile Payment Procedures in Finnish and Chinese Markets." BLED 2009 Proceedings: 37. 